\title{
Zadania i miejsce komórki controllingu w przedsiębiorstwie
}

\section{Wstęp}

Określenie miejsca komórki controllingowej w strukturze przedsiębiorstwa decyduje o sile controllera, postrzeganiu jego jako partnera biznesowego zarządu i możliwości podejmowania przez niego wiążących decyzji. Silna pozycja controllera w przedsiębiorstwie powoduje, że może on brać udział w procesie zarządzania przedsiębiorstwem. W przeciwnym przypadku będzie on tylko rejestratorem zjawisk zachodzących w przedsiębiorstwie i będzie raportował do zarządu stopień realizacji odchyleń od budżetów bez możliwości wpływu na poziom tych odchyleń w przyszłych okresach. Controller stoi na czele komórki controllingu. Według doświadczeń niemieckich komórka controllingu powinna znajdować się $\mathrm{w}$ takim miejscu struktury organizacyjnej, aby mogła jak najskuteczniej realizować swoje zadania. W przedsiębiorstwach dużych controller może być członkiem zarządu. Takie rozwiązanie jest typowe dla firm amerykańskich [Vollmuth 2007, s. 41]. Z perspektywy polskich doświadczeń controller rzadko jest członkiem zarządu, jest natomiast doradcą zarządu w procesie podejmowania decyzji.

W artykule podjęto próbę zweryfikowania przypuszczenia, że rozwiązania dotyczące zadań komórki controllingu i jej miejsca w strukturze organizacyjnej przedsiębiorstw są zindywidualizowane. W celu zweryfikowania tego założenia zostały przeprowadzone badania $\mathrm{w}$ trzech przedsiębiorstwach zróżnicowanych co do wielkości, struktury organizacyjnej oraz branży. Nazwy firm zostały utajnione ze względu na brak zgody zarządów na publikowanie rozwiązań controllingowych badanych firm. 


\section{Wielkość przedsiębiorstwa a komórka controllingu}

Rozwiązania organizacyjne dotyczące komórki controllingu mogą być znacznie zróżnicowane. W praktyce utworzenie i umiejscowienie komórki controllingu w strukturze przedsiębiorstwa zależy od wielu czynników, takich jak: wielkość podmiotu gospodarczego, specyfika i przedmiot jego działalności, długość cyklu produkcyjnego, struktura organizacyjna oraz zakres decentralizacji zarządzania. Niebagatelne znaczenie mają również takie czynniki zewnętrzne, jak otoczenie polityczne i społeczne przedsiębiorstwa, struktura gospodarki, rynki zaopatrzenia i zbytu oraz rynki kapitałowe. Największy wpływ na rozwiązania w obszarze controllingu wydaje się mieć wielkość podmiotu gospodarczego i jego specyfika branżowa.

W małych firmach nie tworzy się wydzielonej komórki controllingu. Funkcję tę pełni właściciel spółki lub prezes jej zarządu jeśli nastąpił rozdział własności od zarządzania. Funkcję controllera może też pełnić asystent prezesa, który będzie na bieżąco analizował stopień realizacji zadań i raportował zarządowi przyczyny odchyleń od założonych planów. Plany przygotowywane są w takich firmach $\mathrm{w}$ dziale rachunkowości, a ocena stopnia ich realizacji wraz z raportowaniem wyników jest dokonywana przez controllera. Controller może mieć $\mathrm{w}$ takich firmach silną pozycję. Może podejmować decyzje dotyczące likwidacji przyczyn odchyleń od planów. Zarząd zajmuje się wówczas monitorowaniem otoczenia, budowaniem pozycji spółki, wytyczaniem strategii rozwoju i bieżąca korektą kierunków tego rozwoju stosownie do zmian otoczenia.

Innym rozwiązaniem jest powierzenie zadań controllera osobie zajmującej się finansami i rachunkowością, jednak takie podejście ma szansę powodzenia tylko w przypadku, gdy osoba ta będzie się odpowiednio dokształcać, by poznać i opanować instrumenty controllingu. Controller musi posiadać bowiem umiejętność starannej analizy zjawisk ekonomicznych i identyfikowania przyczyn odchyleń zależnych i niezależnych od decyzji menedżera. Należy dodatkowo zauważyć podstawową różnicę między rachunkowością a controllingiem. Rachunkowość zajmuje się przeszłością, a controlling wykorzystuje przeszłość do planowania przyszłości. Stąd też osoba zajmująca się w firmie rachunkowością nie zawsze jest w stanie przejąć obowiązki controllera. Wówczas zostaje zatrudniony doradca $\mathrm{z}$ zewnątrz, którego zadaniem jest wprowadzenie i rozwinięcie systemu controllingu. Controller z zewnątrz szkoli dyrekcję przedsiębiorstwa i pracowników zarządu podczas fazy wstępnej aż do momentu, kiedy będą w stanie sami przejąć zadania controllingu [Vollmuth 2007, s. 32]. Jeśli controllerem zewnętrznym jest osoba kompetentna, która zdobyła doświadczenie w innych firmach, wówczas może być bardzo przydatna w rozwiązywaniu problemów firmy. Jest to korzystna opcja dla małych firm, których właściciel sam nie posiada 
niezbędnych umiejętności do wykonywania zadań controllera i nie chce tworzyć dodatkowego stanowiska.

W spólkach średnich wdrażających controlling zanim zostanie podjęta decyzja o powołaniu stanowiska controllera bądź komórki controllingu w pierwszej kolejności analizowany jest zakres kompetencji istniejących komórek organizacyjnych. Bardzo często funkcje controllingowe powierza się działowi rachunkowości zarządczej, działowi finansów bądź działowi analiz. Każde z tych rozwiązań ma wady i zalety. Ulokowanie zadań controllinowych w komórce rachunkowości eliminuje konflikty dotyczące przepływu informacji między komórkami, ale równocześnie powstaje ryzyko przygotowywania budżetów i ich analizy z punktu widzenia ewidencji, nie zaś układu kompetencji. Bardzo często działy księgowości przygotowują budżet firmy w układzie kalkulacyjnym bądź rodzajowym układzie kosztów. Dogodniejszym rozwiązaniem jest wykorzystanie rachunku kosztów zmiennych, gdyż ułatwia on ustalenie odpowiedzialności menedżera za poziom odchyleń od budżetów. Ulokowanie funkcji controllingowych w dziale finansów jest zdecydowanie lepszym rozwiązaniem niż umiejscowienie tej funkcji w dziale rachunkowości. Znacznie szersza jest wówczas analiza przyczyn odchyleń od budżetów. Obejmuje ona przyczyny zewnętrzne, zmiany warunków otoczenia, nie zaś tylko przyczyny ewidencjonowane w systemie rachunkowości. Jednak firmy, które posiadają działy rachunkowości zarządczej lokują funkcję controllingu $\mathrm{w}$ tych działach traktując controlling jako doskonalszy system informacji zarządczej. Takie podejście wydaje się być mocno dyskusyjne jeśli uwzględni się ewolucję systemu controllingu w okresie ostatnich trzydziestu lat. W pierwszym okresie rozwoju controlling był traktowany jako doskonalszy niż rachunkowość system informacyjny dla potrzeb zarządzania przedsiębiorstwem. W miarę rozwoju systemów informatycznych podejście do controllingu od strony ewidencji okazało się być zbyt płytkie w warunkach dynamicznego otoczenia przedsiębiorstw. Znacznie szerzej postrzegana jest funkcja controllingu w nowocześnie zarządzanych przedsiębiorstwach. W przedsiębiorstwach średnich, w których istniały przed wdrożeniem controllingu działy analiz finansowych, zazwyczaj przekształca się je w działy analiz i controllingu. Takie rozwiązanie ma wiele zalet, podobnie jak umiejscowienie controllingu w dziale finansowym. Dział ten gromadzi informacje dotyczące przyczyn odchyleń od planów z wszystkich komórek funkcjonalnych. Jednak powstają wówczas bariery we współpracy z działem rachunkowości, który nie chce umniejszać swojej roli w procesach analizowania zjawisk zachodzących w przedsiębiorstwie.

Realizacja wszystkich zadań, jakie stają przed controllingiem w dużym przedsiębiorstwie, jest możliwa tylko przy wyodrębnieniu działu controllingu. Dział ten może być ulokowany w pozycji liniowej lub sztabowej. Regułą jest jednak, że im wyższa jest jego pozycja, tym większe ma on możliwości zarówno 
wpływania na poszczególne procesy zachodzące w przedsiębiorstwie, jak i efektywnego ich koordynowania [Controlling w matych... 2006, s. 48].

W pozycji liniowej komórka controllingu zajmuje równorzędne miejsce $\mathrm{z}$ innymi działami funkcjonalnymi (rys. 1). Ułatwia jej to współpracę z innymi komórkami liniowymi i pozyskiwanie informacji niezbędnych do ustalenia przyczyn odchyleń od założonych budżetów. Komórka ta ma wówczas łatwiejszą ścieżkę dotarcia do działu marketingu i reklamy, działu finansowego, czy działu rachunkowości. „Dużą zaletą tej struktury jest możliwość podejmowania szybkich decyzji, a także prostota ustalenia kompetencji. Wadą jest natomiast konieczność posiadania kompletnej wiedzy o funkcjonowaniu jednostki. W realiach polskich przedsiębiorstw komórka controlingu najczęściej jest umiejscowiona w pozycji liniowej, często nawet w połączeniu z działem księgowym" [Duda-Piechaczek 227, s. 42].

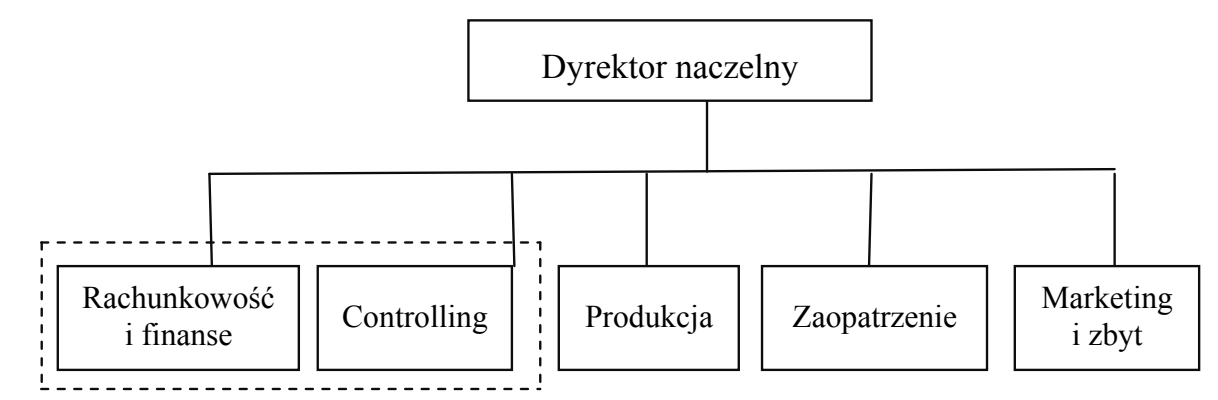

\section{Rysunek 1}

Umiejscowienie komórki controllingowej w pozycji liniowej w strukturze organizacyjnej przedsiębiorstwa

Źródło: H.J. Vollmuth, Controlling. Planowanie, kontrola, kierowanie, Placet, Warszawa 2007, s. 31.

Jednak w początkowym okresie wdrażania systemu controllingu dobrym rozwiązaniem jest podporządkowanie działu controllingu bezpośrednio prezesowi zarządu. Controller zajmuje wówczas wysoką pozycję sztabową w firmie. Stanowiska sztabowe spełniaja zazwyczaj funkcje doradcze, nie mając prawa wydawania zarządzeń i poleceń. Uprawnienia te są jednak ważne w dynamicznie zmiennym otoczeniu firmy, gdyż ułatwiają podejmowanie decyzji mających na celu poprawę sytuacji spółki na rynku [Surmacz i in. 2010, s. 96]. Controller staje się wówczas autentycznym doradcą zarządu, jednak współpraca między komórkami funkcjonalnymi jest wówczas trudniejsza niż przy pierwszym rozwiązaniu. Ulokowanie controllera w pozycji sztabowej powoduje wydłużenie ścieżki przepływu informacji i utrudnienie szybkiej reakcji na powstałe odchylenia w realizacji budżetów poszczególnych centrów odpowiedzialności. 
Zaletą tej struktury jest natomiast możliwość korzystania z opinii wyspecjalizowanych ekspertów, wadą zaś możliwość istnienia sporów między sztabami a kierownikami komórek funkcjonalnych.

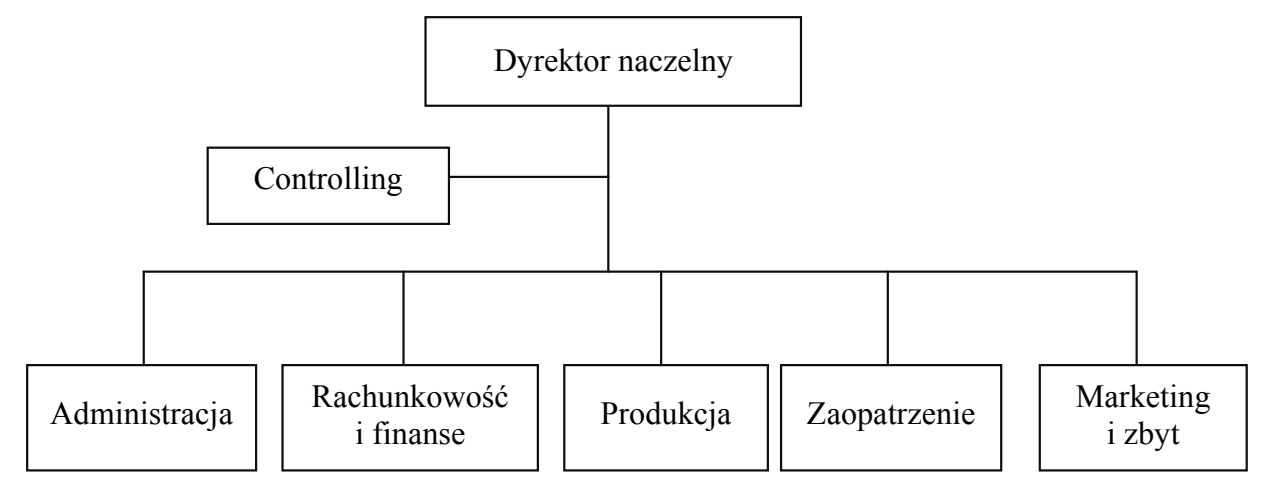

\section{Rysunek 2}

Umiejscowienie komórki controllingowej w strukturze organizacyjnej przedsiębiorstwa według przyporzadkowania sztabowego

Źródło: H.J. Vollmuth, Controlling. Planowanie, kontrola, kierowanie, Placet, Warszawa 2007, s. 30.

Poza wyżej wymienionymi klasycznymi formami rozwiązań dotyczącymi komórki controllingu wymienić można też formy niestandardowe. W przypadku, kiedy działalność spółki ma charakter sezonowy, a więc czas, za jaki oceniany jest na przykład dział sprzedaży, jest ograniczony, zamiast stałej komórki controllingu powołać można doraźnie komisję controllingową. Składa się ze specjalistów oceniających konkretne działania, z uwzględnieniem wszystkich wewnętrznych i zewnętrznych czynników wpływających na osiągane wyniki. Taka forma controllingu występuje też czasami w mniejszych przedsiębiorstwach, w których członkami zespołów problemowych stają się przeważnie kierownicy funkcjonalni [Modele rachunku kosztów... 2004, s. 78].

Inną z metod realizowania funkcji controllingu jest zatrudnianie controllerów zewnętrznych. Zaletą takiego rozwiązania jest postrzeganie przedsiębiorstwa przez takiego controllera w sposób obiektywny, bez jakiegokolwiek wpływu ze strony otoczenia wewnętrznego spółki. $Z$ drugiej jednak strony nie posiada on tak szczegółowej wiedzy o czynnikach wewnętrznych wpływających na wyniki, jak osoba, która jest w nim zatrudniona na stałe. Ponadto może się zdarzyć, że będzie on traktowany jako osoba $\mathrm{z}$ zewnątrz, a więc zaufanie do niego ze strony pracowników może być ograniczone [Stan rozwoju i zakres... 2006, s. 57].

$\mathrm{W}$ rozbudowanych przedsiębiorstwach międzynarodowych o charakterze koncernów, holdingów realizowanie funkcji controllingu jest zdecydowanie 
trudniejsze. Komórki controllingu znajdują się bowiem na różnych szczeblach struktury organizacyjnej tych podmiotów. W układach złożonych struktur grup kapitałowych można wyróżnić [Stan rozwoju i zakres... 2006, s. 57]:

a) Controlling centralny - obszar jego funkcjonowania ma charakter długoterminowy. Controller podlega wówczas bezpośrednio kierownictwu naczelnemu firmy i odpowiada za tworzenie oraz utrzymanie przewagi strategicznej przedsiębiorstwa. Analizuje otoczenie oraz odpowiada za planowanie strategiczne i jego przełożenie na plany operacyjne, współpracuje oraz dostarcza narzędzia controllingu operacyjnego dla dywizji.

b) Controlling dywizji - controller odpowiada bezpośrednio przed kierownikiem dywizji (obszaru). Jego zadaniem jest planowanie, kontrola wykonywanych działań oraz poszukiwanie możliwości usprawnień i nowych metod działania w obszarze dywizji. Do jego obowiązków należy też współpraca $\mathrm{z}$ controllingiem centralnym $\mathrm{w}$ zakresie stosowanych instrumentów i metod postępowania.

c) Controlling funkcjonalny - realizowane przez poszczególne działy funkcje są tutaj podstawą do wyodrębnienia obszaru kompetencji controllera, który podlega bezpośrednio kierownikowi danej funkcji. Przykłady to m.in. controller finansowy, marketingu, czy też controller działalności badawczo-rozwojowej.

d) Controlling projektów - controller działa w grupach projektowych, koordynuje poszczególne projekty i podlega centralnemu controllerowi.

Zadaniem controllera centralnego jest zharmonizowanie działania systemu controllingu w korporacji oraz gwarancja dostarczania informacji i udzielania konsultacji kadrze zarządzającej. Na niższych poziomach tworzone są działy controllingu umieszczone zazwyczaj w pionie ekonomiczno-finansowym obsługującym proces budżetowania jednostek wewnętrznych. Istotna jest przy tym koordynacja działań centrów odpowiedzialności, głównie połączonych technologicznie oraz współdziałania controllerów na różnych poziomach struktury organizacyjnej [Controlling funkcyjny... 2004, s. 152].

\section{Miejsce komórki controllingu w praktyce przedsiębiorstw}

Przeprowadzone badania empiryczne pozwoliły ustalić, że umiejscowienie funkcji controllingu $\mathrm{w}$ strukturze organizacyjnej przedsiębiorstwa ma zawsze charakter zindywidualizowany. Zróżnicowanie między wielkością, rodzajem działalności, czy celami, jakie spółka sobie stawia jest tak duże, że nie da się stworzyć modelowych rozwiązań w tym obszarze.

Rozwiązania dotyczące komórki controllingu zależą od rodzaju wdrażanego systemu controllingowego. Spółka może zdecydować się na układ szczeblowy 
controllingu, wdrażając controlling strategiczny i operacyjny lub układ funkcyjny, tworząc centra odpowiedzialności według funkcji. Wyodrębnione zostaną wówczas controlling badań i rozwoju, controlling logistyki, personalny, produkcji, marketingu, finansowy czy controlling inwestycji. W praktyce wdraża się najczęściej rozwiązanie mieszane szczeblowo-funkcyjne. Wdraża się wówczas controlling strategiczny i operacyjny oraz controlling wybranych ważniejszych funkcji, np. controlling personalny. Jeśli udział kosztów płac w strukturze kosztów jest wysoki, powstaje wówczas potrzeba monitorowania efektywności wykorzystania czynnika ludzkiego. W warunkach, gdy udział surowców i materiałów przeważa w strukturze kosztów wdraża się controlling logistyki. Bardzo często firmy wydzielają controlling finansowy do monitorowania skuteczności realizacji funkcji finansowej. Dotyczy to zazwyczaj krajowych grup kapitałowych oraz międzynarodowych korporacji, gdzie funkcje finansowe są skoncentrowane na szczeblu centrali korporacji.

Ocenę miejsca komórki controllingu w przedsiębiorstwach i zakresu jej kompetencji przeprowadzono w trzech firmach. W spółce „X” należącej do branży cementowej w toku wdrażania controllingu wyodrębniono dział controllingu produkcji i dział controllingu operacyjnego. Ten pierwszy podporządkowany został członkowi zarządu - dyrektorowi do spraw produkcji i technologii, a drugi wiceprezesowi do spraw finansowych. Podporządkowanie komórek controllingu w badanej jednostce prezentuje rysunek 3 .

Rozwiązanie zastosowane w badanej spółce „X” nie jest typowe. Controlling kosztów w zdecydowanej większości przypadków wchodzi w zakres controllingu operacyjnego. Tymczasem $\mathrm{w}$ badanej spółce celem controllingu produkcji

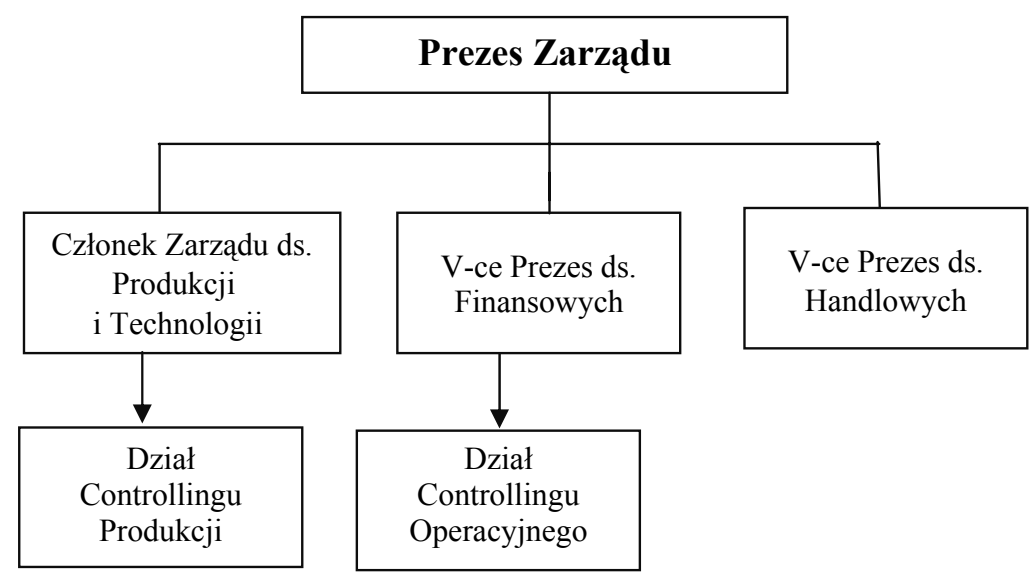

Rysunek 3

Podporządkowanie komórek controllingowych w spółce „X”

Źródło: Opracowanie własne. 


\section{2}

jest racjonalizacja kosztów wytwarzania poprzez maksymalne wykorzystanie czynników produkcji i zapewnienie wysokiej jakości wytwarzanych wyrobów. Dział ten analizuje koszty zużycia materiałów, energii, wydajność pracy przy wykorzystaniu norm zużycia materiałów, wskaźników zużycia energii i norm pracochłonności. Dział controllingu produkcji monitoruje ponadto terminowość realizacji dostaw do odbiorców, zachowanie założonej w planach struktury asortymentowej, zmniejszenie uciążliwości produkcji dla środowiska przyrodniczego oraz zapewnienie bezpieczeństwa i higieny pracy, a w długim okresie miejsc pracy. Dział controllingu produkcji ma swój udział w budowaniu strategii firmy poprzez dostarczanie danych pozwalających na racjonalny dobór technologii produkcji spośród alternatywnych wariantów.

Do zadań controllingu operacyjnego należy planowanie wyników przy wykorzystaniu danych z działu controllingu produkcji dotyczących kosztów oraz przychodów ze sprzedaży na podstawie danych z działu sprzedaży i marketingu. Do zadań tego działu należy również budżetowanie zapasu surowców, budżetowanie zużycia energii będące podstawą kontraktów na dostawy energii, określanie zapotrzebowania na pracowników obecnie i w przyszłości. Spółka wykorzystuje leasing pracowniczy do zapewnienia potrzebnej liczby pracowników. Miesięczne raporty dotyczące wyników i przyczyn odchyleń od budżetów przesyłane są do zarządu. W dziale controllingu operacyjnego analizowane są problemy ryzyka kursowego przy sprzedaży zagranicznej oraz możliwości wykorzystania instrumentów zabezpieczenia tego ryzyka.

Kolejną badaną firmą była polska grupa kapitałowa „BM” notowana na rynku podstawowym GPW z branży metalurgicznej. W jej skład wchodzi spółka matka oraz 8 spółek zależnych. Miejsce komórki controllingu w strukturze organizacyjnej grupy prezentuje rysunek 4 . Grupa ta posiada w swojej strukturze Dział Analiz i Controllingu podporządkowany dyrektorowi finansowemu oraz Dział Nadzoru Właścicielskiego, podlegający bezpośrednio prezesowi zarządu. W dziale tym realizowane są funkcje controllingu udziałowego. Jest on często elementem controllingu finansowego grup kapitałowych. Jednak w analizowanej grupie nie wydzielono komórki controllingu finansowego. Komórka nadzoru właścicielskiego sprawuje funkcję nadzoru nad działalnością spółek zależnych. Doradza w zakresie budowy i realizacji strategii tych spółek w obszarze zgodności ze strategią spółki matki.

Dział ten analizuje również stopień realizacji planów strategicznych i rocznych planów operacyjnych spółek zależnych, ustala przyczyny odchyleń i raportuje do zarządu spółki matki będącego równocześnie zarządem całej grupy kapitałowej. Przygotowuje walne zgromadzenia wspólników spółek zależnych, opiniuje propozycje podziału zysku tych spółek i politykę dywidend. Opiniuje plany inwestycyjne, nadzoruje ich realizację i raportuje do zarządu przyczyny 


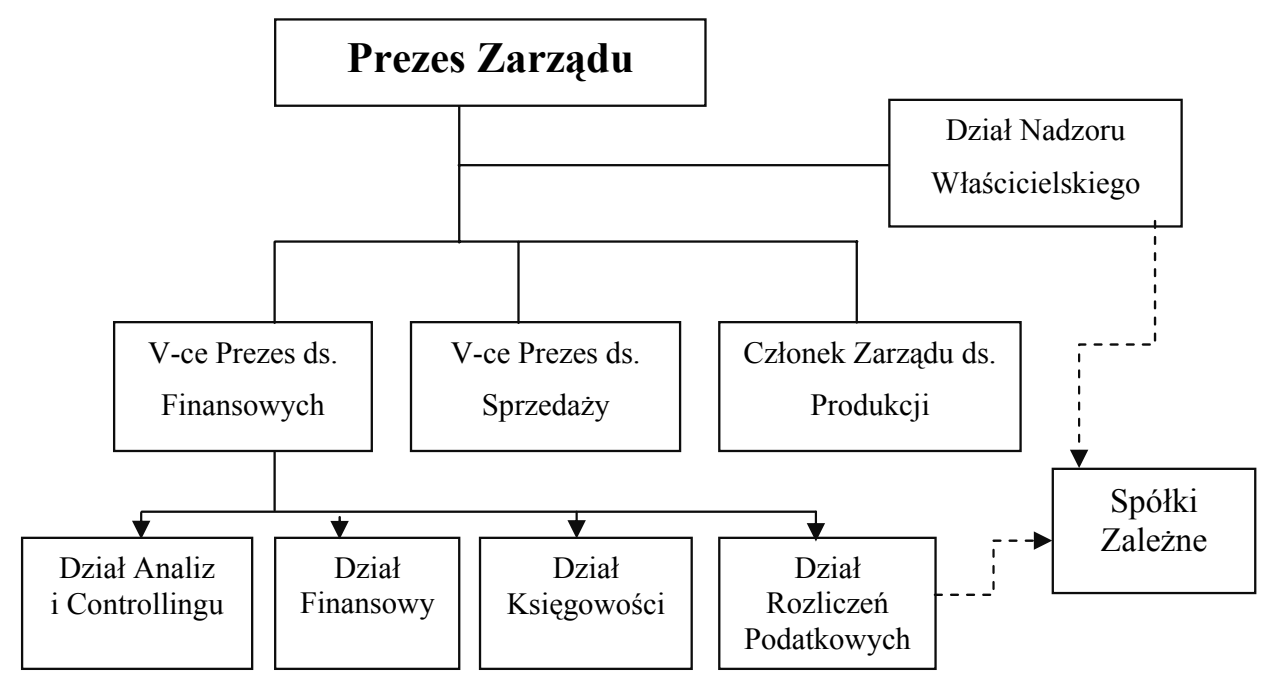

\section{Rysunek 4}

Miejsce komórek controllingu w grupie kapitałowej „BM”

Źródło: Opracowanie własne.

odchyleń od założonych planów. Problemami kształtowania cen transferowych w transakcjach wewnątrzgrupowych i poprawnością rozliczeń podatkowych zajmuje się Dział Rozliczeń Podatkowych.

Zadania Działu Analiz i Controllingu w spółce matce są typowe dla działów controllingowych i sprowadzają się do przygotowania planów i budżetów operacyjnych oraz raportowania stopnia ich realizacji i przyczyn odchyleń. Dział ten analizuje otoczenie i przygotowuje plany strategiczne dla spółki matki. Ważnym zadaniem tego działu jest szczegółowa analiza przyczyn odchyleń od założonych strategii.

$\mathrm{Na}$ rysunku 5 zaprezentowane zostały rozwiązania w obszarze struktury controllingowej międzynarodowej grupy kapitałowej należącej do przemysłu spożywczego. Dział controllingu grupy jest podporządkowany bezpośrednio prezesowi zarządu. Dział ten koncentruje informacje niezbędne do podejmowania decyzji przez zarząd grupy. Merytorycznie działowi temu podlegają departamenty centralnego controllingu produkcji i technologii, sprzedaży, kosztów i finansów. Departamenty te organizacyjnie podlegają również dyrektorowi do spraw finansowych, który jest równocześnie członkiem zarządu.

W spółkach zależnych rozmieszczonych w różnych krajach, m.in. w Polsce, działy controllingu organizacyjnie podporządkowane są prezesowi zarządu, a merytorycznie poszczególnym departamentom. W działach tych zatrudnieni są controllerzy do spraw produkcji i technologii, kosztów, sprzedaży oraz finansów. 
Składają oni raporty zarządowi spółki i przesyłają je również do departamentów centralnych stosownie do specjalizacji.

Głównym celem departamentów jest wspomaganie menedżerów w podejmowaniu decyzji poprzez dostarczenie im wysokiej jakości danych i analiz zarządczych oraz pomysłów, koncepcji i narzędzi, które optymalizują działalność biznesową grupy. Do ich zadań należy ponadto przygotowanie i monitorowanie realizacji planów i budżetów oraz zapewnienie spójności i wysokiej jakości sprawozdawczości finansowej.



\section{Rysunek 5}

Organizacyjna struktura komórek controllingu w spółce $A B C$

Źródło: Opracowanie własne.

\section{Zakończenie}

Reasumując, podkreślić należy, że przeanalizowane trzy przypadki rozwiązań dotyczących zadań i podporządkowania komórki controllingu nie uprawniają do uogólnień naukowych. Pozwoliły one jednak na ustalenie, że rozwiązania dotyczące zadań i miejsca komórki controllingu w strukturze przedsiębiorstwa są zindywidualizowane i zależą od wielkości i specyfiki branżowej podmiotów gospodarczych. 
Biorąc pod uwagę wielkość podmiotu gospodarczego podkreślić należy, że w jednostkach małych tworzy się samodzielne stanowiska controllera bądź zadania controllingu w obszarze budżetowania realizowane są przez księgowość, zaś w obszarze ocen i motywacji przez kierownika jednostki. W spółkach średniej wielkości może być wydzielony dział controllingu lub zadania controllingowe mogą być ulokowane w dziale rachunkowości zarządczej, dziale analiz lub dziale finansowym. W korporacjach, koncernach, dużych grupach kapitałowych na poziomie zarządu funkcjonuje komórka controllingu centralnego, której podporządkowane są działy controllingowe niższych szczebli w strukturze organizacyjnej. W spółkach, w których koszty i jakość produktów zależą od dotrzymania reżimu technologicznego, wydziela się dział controllingu produkcji. W dużych grupach kapitałowych powołuje się dział controllingu finansowego, do którego zadań należy przygotowanie i nadzór nad realizacją strategii finansowej, w tym w szczególności nadzór nad przepływami środków pieniężnych i kapitałów między spółkami grupy. W mniejszych grupach kapitałowych zakres controllingu finansowego sprowadza się do nadzoru udziałowego nad spółkami zależnymi.

\section{Literatura}

Controlling $w$ matych i średnich przedsiębiorstwach, 2006: (red.) A. Kardasz, R. Kotapski, Wydawnictwo AE we Wrocławiu, Wrocław 2006.

Controlling funkcyjny w przedsiębiorstwie, 2006: (red.) M. Sierpińska, Oficyna Ekonomiczna, Kraków.

DUDA-PIECHACZEK E., 2007: Controlling. Wspieranie zarzadzania przedsiębiorstwem, Helion, Gliwice.

Modele rachunku kosztów i rachunkowości zarzq̨dczej, 2004: (red.) E. Nowak, Wydawnictwo AE we Wrocławiu, Wrocław.

Stan rozwoju i zakres stosowania controllingu operacyjnego $w$ matych $i$ średnich przedsiębiorstwach, 2006: (red.) A. Kardasz, R. Kotapski, Wydawnictwo AE we Wrocławiu, Wrocław.

SURMACZ A.O., BROJAK-TRZASKOWSKA M., PORADA-ROCHOŃ M., LUBOMIRSKA-KALISZ J., 2010: Budżetowanie i controlling $w$ przedsiębiorstwie, CeDeWu, Warszawa 2010.

VOLLMUTH H.J., 2007: Controlling. Planowanie, kontrola, kierowanie, Placet, Warszawa.

\section{Abstract}

W artykule zaprezentowane zostały zadania i miejsce komórki controllingu w strukturze organizacyjnej przedsiębiorstwa. Na jej czele stoi controller, który pełni funkcję doradcy ekonomicznego zarządu. Jej głównym zadaniem jest opracowywanie planów operacyjnych i strategicznych, budżetowanie kosztów, przychodów i wyników w krótkich okresach czasu, monitorowanie odchyleń 
od budżetów i planów oraz wyjaśnianie przyczyn tych odchyleń. Rozwiązania dotyczące roli i miejsca komórki controllingu w strukturze organizacyjnej przedsiębiorstw są zindywidualizowane i elastycznie dostosowywane do potrzeb zarządu. Potwierdzają to zaprezentowane w artykule przykłady empiryczne. W pierwszym okresie wdrażania controllingu komórka controllingu jest podporządkowana prezesowi zarządu. Po utrwaleniu jej pozycji w przedsiębiorstwie komórka ta podlega viceprezesowi do spraw finansowych. W krajowych grupach kapitałowych oprócz komórki controllingu operacyjnego wydzielane są działy controllingu finansowego lub działy nadzoru kapitałowego nad spółkami zależnymi. W korporacjach międzynarodowych komórki controllingu występują na kilku szczeblach struktury organizacyjnej i podporządkowane są controllerowi centralnemu.

Słowa kluczowe: controller, komórka controlling, podporządkowanie komórki controllingu

\section{The tasks and place of controlling department in the company}

\section{Abstract}

The paper presents the tasks and place of controlling department in the company. The controller, who is at its forefront, plays the role of economic advisor for the management board. The main tasks of the department are to prepare operational as well as strategic plans, budgeting of costs, revenues and results within short period of time, monitoring the deviations from the budgets and plans and investigating the source of these deviations. The solutions regarding to the role and the place of controlling department in organizational structure are very individual and flexibly adopted to the management board needs. This is proven by the empirical examples given in this paper. In the first stage of controlling introduction process, controlling department is subordinated to CEO. Later, when the position of the department is settled in the company, the CFO takes the control over it. In domestic capital groups financial controlling departments or capital supervision departments over subsidiary companies are additionally formed. In international corporations there are controlling departments on several levels of organizational structure, subordinated to the central controller.

Key words: controller, controlling department, controlling department submission 